\title{
Eksistensi
}

Pemberantasan

Korupsi dalam

Perjanjian Investasi

Internasional

di Indonesia

\section{HESTI WIDYANINGRUM}

Universitas Bhayangkara Jakarta Raya

hestiwidyaningrumo1@gmail.com

p-ISSN 2477-118X

e-ISSN 2615-7977

\section{A B S T R A K}

Perjanjian Investasi Internasional justru dapat melemahkan eksistensi penegakan hukum di Indonesia atas pemberantasan korupsi. Baiknya, Perjanjian Investasi Internasional di Indonesia, perlu mencantumkan pelarangan tindak pidana korupsi dalam kegiatan pra, pasca maupun perpanjangan perjanjian investasi internasional sebagaimana yang dilakukan India dalam model Bilateral Investment Treaty (BIT) mereka. Selain itu, investor dapat menggugat negara atas penegakan hukum korupsi terhadapnya, melalui celah hukum dalam konten fair and Equitable Treatment (FET) dengan alasan "denial of justice." Apalagi konten InvestorState Dispute Settlement (ISDS) mechanism semakin mengguatkan posisi investor di Arbitrase Internasional, karena hanya Investor 
dapat menggugat negara dengan ganti rugi hingga milliaran dollar. Akibatnya, kerugian negara menjadi 2 (dua) kali lipat, kerugian yang timbul akibat tindakan korupsi yang dilakukan pelakunya dan biaya perkara di Arbitrase Internasional. Demikian, sebaiknya Indonesia juga segera mengadopsi konsep FET dalam Indonesia-New Model BIT dimana konten ini membatasi investor untuk menggugat negara sekalipun penegakan hukum pidana.

Kata Kunci: Eksistensi, Pemberantasan Korupsi, Perjanjian Investasi Internasional, Indonesia.

\section{A B S T R A C T}

The International Investment Agreements can actually weaken the existence of law enforcement in Indonesia over the eradication of corruption. Surely, an International Investment Agreements in Indonesia should include a prohibition of corruption in pre, post and International Investment Agreements as India did in their model Bilateral Investment Treaty (BIT). In addition, investors can sue State for corruption law enforcement against him, through legal gap in fair $n$ Equitable Treatment (FET) content on the grounds of "denial of justice." Futhermore, investor-State Dispute Settlement (ISDS) mechanism content further strengthens investors positions in International Arbitration, because only investors can sue countries with compensation of up to billions of dollars. As a result, State losses become 2 (two) times, the losses incurred by the act of corruption committed by the defendant and the cost of the case in International Arbitration. Similarly, Indonesia should also immediately adopt the FET concept in the Indonesia-New Model BIT where this content limits investors to sue State even in criminal law enforcement.

Keywords: Existence, Eradication of Corruption, International Investment Agreements, Indonesia

\section{A. PENDAHULUAN}

Awalnya, korupsi dianggap sangat merugikan investor karena gugatan investor sering kali ditolak oleh Arbitrase Internasional, dengan dalih karena perjanjian investasi yang tercemar korupsi dianggap sebagai perjanjian ilegal sehingga Arbitrase Internasional dianggap sebagai "Safe Habour" bagi negara tuan rumah (host state) untuk membantah gugatan investor (Cao, 2017: 18). 
Sebaliknya, jika dilihat sebenarnya bukan hanya investor yang dirugikan, tetapi negara tuan rumah (Host State) lebih dirugikan lagi oleh korupsi. Dimana kegiatan investasi yang tercemar korupsi oleh investor itu sendiri, justru dapat dijadikan dasar untuk mengajukan gugatan di Arbitrase Internasional ketika Host State menegakkan hukumnya terhadap investor yang melakukan tindak pidana korupsi di negara tersebut.

Seperti yang dilakukan oleh Alwarraq terhadap pemerintah Indonesia dengan tuntutan sebesar 19, 8 juta US dollar atau setara dengan 1,3 triliun rupiah di Aribtrase Internasional pada tahun 2011 silam dengan dalih putusan in Absentia Pengadilan Tindak Pidana Korupsi terhadapnya menimbulkan kerugian terhadapnya (Alwarraq V Indonesia Final Award, 2011). Munculnya gugatan Alwarraq tersebut, didasari dengan adanya Agreement On Promotion, Protection And Guarantee Of Investments Among Member States Of The Organisation Of The Islamic Conference.

Kedua hal yang kontradiktif ini, menunjukkan bahwa sebenarnya Perjanjian Investasi Internasional dapat merugikan kedua belah pihak jika terjadi korupsi di dalam kegiatan investasi tersebut. Apalagi situasi ini makin mengkhawatirkan bagi Indonesia khususnya, dimana hampir semua Perjanjian Investasi Internasional yang ada di Indonesia sejak tahun 1960-an hingga saat ini tercatat masih memiliki sekitar 43 Perjanjian Investasi Bilateral (Bilateral Investment Treaties) yang masih efektif dan baru ditandatangani (UNCTAD, 2018). Kesemua perjanjian tersebut memilih penyelesaikan sengkata di Arbitrase Internasional termasuk juga perjanjian multilateral seperti perdagangan bebas (Free Trade Agreement) Seperti ACFTA (Asean-China Free Trade Agreement), ASEAN-FTA (ASEAN Free Trade Agreement), dan negosiasi perjanjian yang masih berlangsung oleh Indonesia dalam EU-CEPA (Europe Union Comprehensive Partnership Agreement) dan RCEP (Regional Comprehensive Economic Partnership) sampai saat ini (Retno, 2018: 15).

Kondisi ini semakin dilematis, satu sisi pemberantasan korupsi diperlukan, karena korupsi selama ini merupakan kendala dalam peningkatan investasi melalui Perjanjian Investasi internasional (Pusat Kebijakan Regional dan Bilateral Kementerian Keuangan RI, 2012: 13). Hal ini karena investasi asing saat ini masih sangat berperan dalam mendorong pertumbuhan ekonomi nasional dimana investasi asing masih mendominasi di Indonesia, sebesar 58,8\% dari 
total investasi dan meningkat sebsar 11,8\% dari tahun 2017 sehingga tembus 185,3 triliun rupiah dan mampu meningkatkan industri nasional sebesar 38\% (BKPM, 2018: 5).

Disatu sisi yang lain, Investor asing sendiri justru mengingkari pemberantasan korupsi itu sendiri. Hal ini dapat dilihat pada tindakan Alwarraq yang tidak kooperatif terhadap penegakan hukum pemberantasan korupsi. Dimana sejak Alwarraq menjadi daftar pencarian orang bulan Desember 2008 yang berkaitan dengan kasus korupsi Bank Century hingga proses peradilan tahun 2010, Alwarraq tidak pernah hadir sampai akhirnya Pengadilan Negeri Jakarta Pusat mengadilinya dengan peradilan In Absentia dalam putusan Nomor: 339/ Pid. B/ 2010/ PN.JKT.PST yang menyatakan Hesham Alwarraq bersalah melakukan tindak pidana korupsi dan pencucian uang yang dihukum penjara selama 15 tahun dan membayar uang pengganti sebesar Rp. 3.115.899.000.000

Ini adalah kosekuensi atas perbuatannya menyalahgunakan kewenangan selaku pemegang saham mayoritas Bank Century melalui Perusahaan First Gulf Asia Holdings Limited dengan menjual Surat-Surat Berharga (SSB) yang tidak sehat/macet kepada perusahaan investasi di luar negeri sehingga berakibat pada kondisi keuangan Bank Century yang memburuk dan mengalami kesulitan untuk dilakukan likuidasi. Ditambah hasil penjualan surat-surat berharga tersebut tidak ditempatkan sebagai milik Bank Century melainkan pada perusahaan milik pribadinya, First Gulf Asia Holdings Limited sehingga penempatan ini tidak diketahui oleh Bank Century. Akibatnya, Bank Century masuk dalam kategori bank gagal yang berdampak sistemik sehingga negara melalui Lembaga Penjamin Simpanan (LPS) mengambil langkah dengan memberikan dana Penyertaaan Modal Sementara (PMS). Perbuatan Al-Waaraq ini mengakibatkan negara mengalami kerugian sebesar Rp. 3.115.899.000.000.

Sayangnya, penegakan hukum dalam rangka pemberantasan korupsi ini justru menjadi umpan balik bagi Alwarraq mengajukan gugatannya di Arbitrase Internasional melalui Perjanjian Investasi Internasional (Alwarraq V. Indonesia Final Award, 2011). Ringkasnya, adanya Perjanjian Investasi Internasional justru membuat negara tuan rumah berpotensi tidak mampu menegakkan hukum nasionalnya sendiri (Johnson dan Volkov, 2013: 49).

Kontradiksi ini yang mendorong penulis ingin mengkaji mengenai persoalan keberadaan Perjanjian Investasi Internasional di Indonesia 
terhadap pemberantasan Korupsi. Hal ini yang kemudian menjadi dasar Penulis dalam membuat kajian ini dengan judul "Eksistensi Pemberantasan Korupsi dalam Perjanjian Investasi Internasional di Indonesia."

\section{Rumusan Masalah}

Berdasarkan latar belakang di atas, maka fokus permasalahan dalam kajian ini, yakni:

a. Bagaimana eksistensi pemberantasan korupsi dengan adanya Perjanjian Investasi Internasional di Indonesia?

b. Apa sajakah hal-hal yang menjadi dasar gugatan oleh investor yang berpotensi melemahkan eksistensi pemberantasan korupsi melalui Perjanjian Investasi Internasional di Indonesia ke depan?

\section{Tujuan Kajian}

Penulisan ini bertujuan untuk:

a. Menganalisis hubungan adanya Perjanjian Investasi Internasional di Indonesia dengan eksistensi pemberantasan korupsi.

b. Mengetahui dan menganalisis adanya celah hukum dalam Perjanjian Investasi Internasional sebagai dasar gugatan investor atas penegakan hukum pemberantasan korupsi di Indonesia sehingga memperlemah pemberantasan korupsi.

\section{Metode Penelitian}

Pada penulisan ini, Penulis memilih menggunakan metode penelitian normatif, dengan menggunakan pendekatan konseptual, Perundang-undangan, kasus, dan Comparative Law Study dengan India dan Indonesia Model BIT (Bilateral Investment Treaty).

\section{Kerangka Teori}

Pada penulisan ini, ada 2 (dua) teori yang digunakan Penulis sebagai landasan dasar kajian dalam penulisan ini, pertama asas teritorial, dimana pemberlakuan hukum pidana terhadap setiap orang yang melakukan tindak pidana di suatu wilayah tempat berlaku hukum tersebut (Hamzah, 2008: 64). Kedua, asas Par in Parem Non Hebet Imperium, mengandung makna pelarangan penerapan yuridiksi antar negara yang berdaulat terhadap negara lain, terkecuali 
pada badan atau pribadi yang lebih rendah kedudukannya dari negara tersebut (Parthiana, 1990: 320).

\section{B. PEMBAHASAN}

\section{Perjanjian Investasi Internasional berpotensi melemahkan Eksistensi Pemberantasan korupsi di Indonesia}

Menurut laporan OECD (Organisation for Economic CoOperation and Development) bahwa 1\% peningkatan korupsi akan mengurangi pertumbuhan ekonomi sebesar 0.73\% dan akibat korupsi berdampak pada penambahan biaya 10\% dalam bisnis (Makhlouf, 2016:36). Oleh karena itu, korupsi sangat merugikan baik bagi negara tuan rumah dan investor dalam kegiatan dunia bisnisnya. Tentu, ini salah satu alasan dibentuknya The United Nations Convention against Corruption (UNCAC) 2003 dan disahkan oleh negara-negara untuk mencegah timbulnya kerugian akibat korupsi yang terjadi (Cao: 2017: 7).

Sayangnya, meski UNCAC sudah diberlakukan seluruh dunia, namun korupsi masih saja menimbulkan masalah dalam dunia bisnis, khususnya Investasi. Menurut laporan Indonesian Corruption Watch (Kompas, 2012) sektor yang paling tinggi korupsinya adalah investasi. Akibatnya, investor tidak jarang untuk mencari keadilan di Arbitrase internasional daripada di pengadilan domestik suatu negara. Hal ini disebabkan oleh berbagai faktor di antaranya proses pengambilan keputusan lebih independen, imparsial, dan tepat waktu (Widyana, 2011: 252-253) hingga dapat menarik kembali wewenang Arbiter jika terindikasi melakukan tindakan koruptif (Abdurrasyid, 2011: 77-82).

Namun, apa yang terjadi justru sebaliknya. Diawali kasus yang pertama kali muncul, pada tahun 1963 mengenai gugatan seorang teknisi Argentina yang bekerja di perusahaan Inggris, namun gugatan yang diajukan oleh teknisi tersebut ditolak oleh hakim bernama Lagergren dikarenakan ketika perjanjian yang dibuat tercemar oleh tindakan korupsi, tidak dapat dijadikan legal standing dalam pengajuan gugatan di Arbitrase Internasional (Martin, 2002: 3). Hal yang sama juga terjadi dalam putusan Word Duty FreeV. Kenya (ICSID Case No. ARB/Oo/7a, 2006) dan Metal Tech V. Uzbekistan (ICSID Case No. ARB/10/3, 2013). Ilegalnya perjanjian tersebut didasari karena korupsi merupakan tindakan yang bertentangan dengan 
kepentingan publik Internasional ${ }^{1}$. Hal ini Sejalan dengan Article 16 UNCAC 2003 yang telah mewajibkan pejabat asing, termasuk Arbiter untuk tidak bertindak apabila berkaitan dengan kejahatan korupsi di dalam suatu gugatan yang diajukan oleh investor yang terlibat kasus korupsi di negara tuan rumah.

Sayangnya, tidak semua Arbiter berlaku demikian. Ada sebagian Arbiter mengganggap kewenangan Arbiter hanya terbatas pada penyelesaian kepentingan kedua belah pihak, artinya Arbiter tidak dapat melihat aspek lain walaupun gugatan yang diajukan oleh investor sekaligus juga pelaku perkara korupsi ${ }^{2}$. Semisal dalam putusan Niko Resource V. Bangladesh (ICSID Case No. ARB/10/18) dimana Arbiter memenangkan pihak Niko Resource walaupun secara nyata Niko Resource adalah terpidana korupsi di negara Bangladesh (Reeder, 2016: 315). Kasus di Bangladesh ini juga dialami oleh Indonesia, dimana Arbitrase Internasional tetap menerima gugatan Alwarraq yang sekaligus terpidana korupsi dalam peradilan In Absentia di Pengadilan Negeri Jakarta Pusat tahun 2011 silam. Kedua situasi ini mengisyaratkan terjadi perbedaan perspektif terhadap Arbiter ketika menanggani suatu sengketa yang berkaitan dengan kasus korupsi.

Situasi ini justru membuat negara tuan rumah semakin dilematis, karena gugatan investor yang sekaligus sebagai pelaku tindak pidana korupsi di negara tuan rumah tidak selamanya ditolak oleh Arbitrase

1 Pendapat Richard Kreindler, bahwa "illegality contentions going to the nullity of the main contract... even if initiated by the tribunal itself, should normally be deemed to fall within the terms of the submission to arbitration'... [as] it has a core relevance to... public policy... [and] should be seen as necessarily falling within the terms of virtually any submission to arbitration... a tribunal-initiated investigation of illegality is not tantamount to ultra petita [as] [t]he tribunal comes to a legal conclusion as to the validity of the main contract, the claims under that contract... or the unmeritoriousness of the claims due to the invalidity of the contract... The Tribunal's decision following on such self-initiated investigation can fit' into the claims and... defences already made." yang dikutip oleh Michael Hwang and Kevin Lim, "Corruption in Arbitration, Law and Reality,"Corruption in Arbitration, Law and Reality. Asian International Arbitration Journal (AIAJ), Volume 8 No. 1 Tahun 2012, hal. 68, (http://www.arbitration-icca.org/media/4/97929640279647/ media013261720320840corruption_in_arbitration_paper_draft_248.pdf, diakses tanggal 26 mei 2018)

2 Tran Bao Cao, "Proving Corruption Allegation....” Op. Cit., hal. 13-17. Tulisan ini menerangkan bahwa ketika korupsi dijadikan bagian dalam sengketa, maka putusannya pun tergantung pada presfektif Arbiter. Jika kewajibannya kepada publik, maka dapat menjadi bagian dalam sengketa dalam rangka memerangi korupsi sebagai internasional public policy. Namun, jika kewajibannya kepada para pihak, maka korupsi tidak dapat menjadi bagian dalam sengekta, karena itu tergantung pada kebutuhan pihak-pihak. 
Internasional sehingga tidak selamanya sejalan dengan kehendak negara tuan rumah dalam upaya pemberantasan korupsi yang terjadi di negaranya.

Pasalnya, penyelesaian sengketa melalui Arbitrase Internasional memiliki kelemahan tersendiri dimana hukum yang berlaku bukanlah hukum negara tuan rumah melainkan hukum dimana Lembaga Arbitrase Internasional atau hukum yang dipilih oleh para pihak (Adolf, 2015: 142). Sebagaimana merujuk pada asas Pacta Sund Servanda. ${ }^{3}$

Semisal, ketika Perjanjian Investasi Internasional memilih penyelesaian sengketa di Arbitrase Internasional menurut ICSID (International Centre For Settlement of Investment Disputes) Convention di Wasington, maupun UNCITRAL (United Nations Commission International Trade Law) Model Law di Perancis, maka otomatis yang berlaku bukan hukum nasional kita. (Nugroho, 2015: 30-328). Tentunya, negara tidak memiliki yuridiksi lagi dalam menegakkan hukum di negaranya sendiri, jika investor membawanya sengketa tersebut di Arbitrase Internasional (Adolf, 2014: 209).

Situasi ini yang dapat dimanfaatkan oleh investor, sama seperti yang dilakukan oleh Alwarraq ketika menggugat Indonesia melalui klausul yang tercantum dalam Article 17 Agreement On Promotion, Protection And Guarantee Of Investments Among Member States Of The Organisation Of The Islamic Conference, dimana para pihak dapat menyelesaian sengketa di Arbitrase Internasional (ICSID Case No. ARB/11/13, 2011).

Klausul ini dijadikan celah bagi Alwarraq untuk membawa perkara pidana keluar dari batas wilayah Indonesia. Konsekuensinya, hukum yang digunakan dalam penyelesaian sengketa itu tidak selamanya mewakili kepentingan salah satu pihak yang bersengketa walaupun sengketa yang terjadi berkaitan dengan upaya negara tuan rumah dalam pemberantasan korupsi yang terjadi di negaranya. Secara otomatis, penyelesaian sengketa di Arbitrase Internasional, dapat melemahkan kedaulatan negara dalam menegakkan hukum nasionalnya atas pelanggaran tindak pidana korupsi yang telah diatur dalam undang-undang secara hukum yang berlaku.

3 Bryan A. Garner, Black's Law Dictionary (Eight Edition), (USA: Thomson West, 2004), hal. 1140. Pacta Sund Servanda is "Agreement must be kept, the rule that agreement and stipula tion, esp. Those contained in treaties, must be observed." 
Padahal Indonesia adalah negara yang berdaulat sebagaimana tertuang dalam Pembukaan Undang-Undang Dasar Negara Republik Indonesia Alenia ke-2, artinya pemerintah Indonesia memiliki kekuasaan penuh dalam menegakkan hukum di wilayahnya. Penegakan hukum terhadap Alwarraq adalah salah satu wujud dari kedaulatan negara, dalam aspek intern kedaulatan dan teritorial kedaulatan. ${ }^{4}$

Sebagaimana disebutkan dalam KUHP pasal 2 bahwa "Siapapun yang melakukan delik di wilayah negara tempat berlakunya hukum pidana tunduk pada hukum pidana itu." Hal ini juga dikuatkan dalam Konvensi United Nations Convention Against Corruption (UNCAC) yang mengakui kedaulatan negara-negara untuk melaksanakan pemberantasan korupsi melalui kebijakan dan penegakan hukum yang dibentuk oleh setiap negara tersebut, yang tertuang dalam Pasal 4 dan 5 UNCAC 2003.

Akhirnya, Perjanjian Investasi Internasional memberikan keterbatasan bagi suatu negara tuan rumah, khususnya Indonesia dalam penegakan hukum nasional terkait dengan pemberantasan korupsi baik dalam segi materil dan formil ${ }^{5}$ ketika adanya gugatan yang diajukan di Arbitrase Internasional oleh investor sekaligus pelaku tindak pidana korupsi.

Dengan demikian menurut Penulis, Pertama, di sinilah peran pengadilan sangat penting untuk men-counter gugatan di Arbitrase Internasional, dimana pengadilan dapat menolak putusan arbitrase asing atas gugatan penegakan hukum pemberantasan korupsi yang bertentangan dengan asas (public order) kepentingan umum. Sebagaimana diakui dalam New York Convention Pasal 5 ayat 2

4 Boer Mauna, Hukum International Pengertian Peranan dan Fungsi dalam Era Dinamika Global, (Bandung: Alumni, 2015), hal. 24. Aspek intern Kedaulatan disebutkan sebagai "Hak atau wewenang eksklusif suatu negara untuk mementukan lembaganya, cara kerja lembaganya, pembuatan undang-undang, serta tindakan-tindakan untuk mematuhi. Aspek Teritorial Kedaulatan berupa kekuasaan penuh dan eksklusif oleh negara atas individu-individu dan bendabenda yang terdapat di wilayah tersebut.

5 Dan Evi Hartanti, Tindak Pidana Korupsi, (Jakarta: Sinar Grafika, 2007), hal. 99-100. Disebutkan bahwa upaya pemerintah Indonesia dalam pemberantasan korupsi, tidak hanya membentuk hukum materil saja yang diatur dalam KUHP dan Undang-Undang Nomor 31 Tahun 1999 dan Undang-Undang Nomor 20 Tahun 2001 tentang Pemberantasan Tindak pidana Korupsi, melainkan juga membentuk lembaga antikorupsi sejak tahun 1960 bernama Tim Pemberantasan Korupsi hingga tahun 2002 bernama Komisi Pemberantasan Korupsi (KPK). 
dan UNICTRAL (United Nations Commission International Trade Law) Model Law Pasal 34 ayat 2. Ini juga sejalan dengan sistem hukum Indonesia, sebagaimana diatur dalam Peraturan Mahkamah Agung No. 1 Tahun 1990 kemudian diadopsi dalam UU. Nomor 30 Tahun 1999 Pasal 62 ayat 2 dimana putusan arbitrase asing tidak boleh bertentangan dengan ketertiban umum, artinya tidak boleh bertentangan dengan hal-hal yang merupakan kepentingan asasi masyarakat Indonesia, yang penting secara ekonomi dan sosial walau digantikan dengan hukum asing (Nugroho, 2015: 422).

Kedua, peran pemerintah juga tidak kurang penting dalam hal ini. Dimana penentuan kebijakan investasi, mestinya juga mempertimbangan kepentingan nasional, sebagaimana disebutkan dalam Pasal 4 Undang-Undang Nomor 24 Tahun 2000 tentang Perjanjian Nasional. Kepentingan nasional di sini, bukan hanya ekonomi tetapi juga termasuk aspek hukumnya. Jangan sampai Perjanjian Investasi Internasional, akhirnya melemahkan pemberantasan korupsi di Indonesia. Baiknya, Pemerintah lebih cermat dalam menyepakati klausul perjanjian investasi yang dibuat dengan investor asing. Kasus Alwarraq juga dapat diambil sisi posisi positifnya, dimana Arbitrase Internasional menolak gugatan Alwarraq karena adanya klausul perjanjian tersebut Pasal 9 yang mengatur kewajiban setiap pihak untuk_menahan diri dari tindakan yang menganggu kepentingan publik dan tidak berhak atas pengajuan kerugian yang timbul akibat tindakan pihak tersebut. Tindakan menahan diri ini masih bersifat luas, sehingga perlu lebih dipertegas termasuk pada tindakan korupsi.

Kita bisa melihat perbandingan di India Model BIT dimana terkandung ketentuan dalam salah satu babnya yakni "Obligation Against Corruption in Article 9. Menariknya, dalam pasal ini hanya menekankan pelarangan terhadap investor untuk tidak menyuap pejabat negara atau individu-individu dalam pembuatan perjanjian, mempertahankan keuntungan dalam kegiatan investasi, berkontribusi secara ilegal terhadap pemilihan pejabat publik atau partai politik atau organisasi politik lainnya termasuk membantu menghasut, berkonsipirasi untuk terjadinya kegiatan penyuapan untuk kepentingan investasinya. Melihat model BIT ini, maka jelas India telah melakukan sinergi antara kebijakan investasi dan kebijakan pemberantasan korupsinya di negaranya dengan 
pelarangan tindakan korupsi pra dan pasca perjanjian dibuat ${ }^{6}$.

Seperti di India, menurut Penulis kita juga perlu mencantumkan pelarangan tindak pidana korupsi dalam perjanjian investasi kita dengan investor baik dalam kegiatan pra, pasca maupun perpanjangan perjanjian investasi internasional di Indonesia. Hal ini sebagai upaya menguatkan eksistensi pemberantasan korupsi dalam perjanjian investasi internsional di Indonesia.

\section{Investor asing dapat menggugat negara (Host State) melalui celah hukum dalam Perjanjian Investasi Internasional}

Bila dihubungkan dengan pembahasan pertama, konten FET (Fair and Equitable Treatment) yang paling dapat dijadikan celah bagi investor mengugat negara dengan dalih negara melanggar perjanjian ketika negara melalui penegakan hukumnya melakukan pemberantasan korupsi terhadapnya. Apalagi konten ini paling banyak dikabulkan atas gugatan investor dalam sengketa di Arbitrase Internasional. ${ }^{8}$

Konten ini dapat menjadi "dasar" bagi investor untuk bebas dari tuntutan pidana terhadap korupsi yang dilakukannya, karena ruang lingkup Fair and Equitable Treatment biasanya juga termasuk dalam ruang lingkup "Due Process of Law"9 dalam penegakan

6 Hal ini dapat merujuk pada ketentuan dalam Undang-Undang Nomor. 31 Tahun 1999 Jo. Undang-Undang Nomor 20 Tahun 2001 tentang Pemberantasan Tindak Pidana Korupsi.

7 Kenneth J. Vandevelde, "A Unified Theory of Fair and Equitable Treatment," New York University Journal of International Law \& Politics, Volume 43 No. 1 in 2010, hal. 45. Disebutkan bahwa prinsip ini awal muncul dalam Havana Charter for an International Trade Organization dan theEconomic Agreement of Bogotá tahun 1948. Kemudian diadopsi pertama kali oleh Jerma-Pakistan BIT tahun 1959, dan berkembangan BIT di negara-negara lain sebagaimana disebutkan dalam UNCTAD, "Fair and Equitable Treatment," (http://unctad. org/en/Docs/unctaddiaeia2011d5_en.pdf, diakses tanggal 1 Juni 2018), hal. 5-6. Definisinya adalah "The fair and equitable treatment standard is an absolute standard of protection. It applies to investments in a given situation without reference to how other investments or entities are treated by the host State. Thus host governments are unable to resist a claim under this standard by saying that the treatment is no different from that experienced by their own nationals or other foreign investors operating in their economy."

8 UNCTAD, “ISDS: Review of Development in 2017", (http://unctad.org/en/ PublicationsLibrary/diaepcbinf2018d2_en.pdf, diakses tanggal 1 Juni 2018), hal. 5

9 Kenneth, Op. Cit., hal. 89. 
hukum domestik/ hukum suatu negara tuan rumah (Host State). Seperti Alwarraq lakukan di Arbitrase International. Artinya, perjanjian investasi secara tidak langsung akan semakin melemahkan penegakan hukum terhadap korupsi dan melegalkan tindakan korup yang dilakukan investor asing. Apalagi, dalam draft perjanjian RCEP (Regional Comprehensive Economic Partnership) dan EUCEPA (Europe Union Comprehensive Partnership Agreement) yang sedang dinegosiasikan oleh Pemerintah Indonesia saat ini, konten FET tersebut semakin diperluas dan dipertegas dalam melindungi investor dari jeratan hukum negara tuan rumah (host state). Oleh karena, isi draft perjanjian tersebut tidak pernah dipublikasikan pada masyarakat, maka dapat dilihat dengan diperbandingan dalam isi EU-Vietnam CEPA, konten FET, disebutkan bahwa:

" $A$ breach party breaches the obligation of fair and Equitable Treatment referencedin paragraph 1 where a measure or series of measure constitutes, denial ofjustice in criminal, civil, or administrative proceddings...."

Konten FET ini semakin diperjelas, dimana negara dilarang melanggar konten FET, yang ditemui ada tindakan "Denial of Justice $^{11}$ in criminal," ini mengartikan bahwa investor dapat melakukan gugatan dengan hanya "asumsi" dan "justifikasi" bahwa telah terjadi penegakan hukum pidana yang tidak adil bagi investor sehingga merugikannya. Pada akhirnya, perjanjian investasi saling kontraproduktif dengan pemberantasan korupsi, dimana perjanjian investasi akhirnya ditempatkan untuk meletigimasi setiap perbuatan koruptif dalam kegiatan investasi, demi melancarkan kegiatannya.

Apalagi, hampir semua perjanjian investasi internasional di Indonesia, terdapat konten Investor-State Dispute Settlement mechanism. ${ }^{12}$ Mekanisme ini semakin menguatkan posisi investor sebagai

10 Indonesian Global Justice. Workshop Paper: Comparison of Investment Chapter in RCEP, EU-Vietnam CEPA. Workshop on Investment Portection and ISDS in Asia.17-19 November 2016. Manila, Philipina. Bahan ini didapat oleh penulis di acara tersebut di Philipina.

11 Recca Ayu Hapsari, "Pertanggungjawaban Negara terhadap Pengingkaran Keadilan dalam Arbitrase Internasional”, Jurnal Ilmu Hukum Pranata Hukum, Universitas Bandar Lampung, Vol. 11 No.1 Tahun 2016, hal. 21. Denial of Justice merupakan pengingkaran keadilan yang dapat dilakukan pihak Investor dengan alasan adanya penyelenggaran peradilan yang tidak adil bagi investor.

12 Sachet and Sooraj, "Investor-State Dispute Settlement Mechanism: The Quest for a Workable Roadmap," Utrech Jurnal of International and European Law, 
penggugat di Arbitrase Internasional. ${ }^{13}$ Oleh karena itu, mereka dapat mengajukan nilai kompensasi dari jutaan hingga miliaran dollar. ${ }^{14}$ Selain itu juga, negara ketika bersengketa harus mengeluarkan biaya untuk Arbitrator sebesar 3.00o Dolar Amerika per hari (ICSID, 2018) dan itu belum termasuk biaya lainnya, Pemerintah Indonesia sudah kerugian miliaran dollar akibat mekanisme ini. Diawali ketika Indonesia kalah atas gugatan Amco sebesar 3,2 juta Dolar Amerika (WorldBank, 1988: 167). Kemudian, kasus gugatan Churchill Mining yang nilainya mencapai 26,8 triliun rupiah dan terbesar sepanjang Sejarah. Ditambah biaya berperkara yang sudah dikeluarkan oleh pemerintah Indonesia sebesar 8 juta-an Dolar Amerika (Churchill Mining V. Indonesia Award, 2016). Selain itu juga, pada kasus Newmont, Pemerintah sudah mengeluarkan biaya perkara sebesar 1,9 juta Dolar Amerika (Kontan, 2009). Walaupun pada akhirnya, PT. Newmont mencabut gugatannya (Vas dan Damanik, 2014), termasuk gugatan Alwarraq dengan tuntutan ganti rugi sebesar 19.8 juta Dolar Amerika dan belum termasuk biaya perkara yang mencapai sekitar 6.9 juta Dolar Amerika (Alwarraq Award, 2011).

Hal ini kontraproduktif dengan tujuan pemberantasan korupsi dalam mengembalikan aset negara. Akhirnya, negara harus mengalami kerugian 2 (dua) kali lipat atas tindak pidana korupsi,

Vol. 29 No. 76 in 2013, hal. 89-90. (file:///C:/Users/ACER/Downloads/41-411-PB.pdf, diakses tanggal 1 Juni 2018) Disebutkan bahwaISDS (Investor-State Dispute Settlement) merupakan evolusi atas konsep penyelesaian sengketa yang awalnya antara state to state, berubah menjadi Investor to State. Pada tahun 1965 mekanisme ini diakui oleh negara-negara yang di adopsi dalam ICSID. Mekanisme ini pertama kali ada dalam BIT antara Indonesia-Netherland Tahun 1968.

13 NGO-Transnational Institute. Back to Basic: The Most Common Pro-ISDS claims are not supported by Evidence. "Winning Te Debate, Against Pro ISDS Voices, An Activist's ArgumentGuide,”2016, hal. 10-25 (https://www. ttip-stoppen.at/wp-content/uploads/2016/o8/winning-the-debate-againstpro-isds-voices.pdf, diakses tanggal 1 Juni 2018), mengatakan bahwa ISDS mechanism membuat:

- $\quad$ Protection standards in investment agreements are not limited to extreme sovereign abuse or discrimination,

- $\quad$ State always lose even they win and settle case,

- By putting enormous pressure on public budgets, ISDS claims can push governments to think twice about regulatory measures, postpone them, or even weaken regulation,

- ISDS risks undermining the rule of law by creating a parallel system to the legal systems in force and ext.

14 UNCTAD, “ Review ISDS ... Op. Cit. hal. 7. Pada bagian Decision in 2017: an Overview ini menjelaskan berbagai putusan Arbitrase Internasional di seluruh dunia, yang dimana nilai ganti kerugiannya jutaan hingga miliaran dollar. 
pertama kerugian yang timbul akibat korupsi oleh pelaku. Kedua, Negara harus mengeluarkan dana kembali untuk me-respons gugatan yang diajukan pelaku tindak pidana korupsi di Arbitrase Internasional.

Jika begitu, maka dapat diketahui bahwa sekalipun negara itu bersih dari korupsi, bukan berarti tidak ada kemungkinan akan adanya gugatan di Arbitrase International melalui mekanisme Investor-State Dispute Settlement. Bisa kita lihat pada data, Kanada yang juga termasuk negara bersih dari korupsi dalam urutan ke-8 berdasarkan index korupsi (Transparancy International, 2017) juga sebagai salah satu negara yang menerima banyak gugatan di Arbitrase Internasional oleh investor asing (Wellhausen, 2016: 16) Singkatnya, investor akan melakukan gugatan di Arbitrase Internasional atas apapun tindakan atau kebijakan pemerintah (Host State) sekalipun berhubungan dengan pemberantasan korupsi. Selama tindakan pemerintah dianggap merugikan dan menghambat investasinya. Oleh karena itu, keberadaan perjanjian investasi memang diperuntukkan demi kepentingannya. Hal ini juga ditegaskan oleh Joseph Stiglitz dalam tulisannya Alfred- Maurice De Zayas (2016: 6) bahwa:

"Corporation everywhere may well agree that getting rid regulation would be good corporate profit, Trade negosiator might be persuaded that these agreement would be good for trade and corporate profit."

Ini kembali lagi pada kebijakan investasi kita, semestinya berjalan searah dengan pemberantasan korupsi di Indonesia. Baiknya konten FET dalam perjanjian investasi kita selama ini harus segera direvisi, dan mengadopsi Indonesia New Model BIT kita yang disebutkan bahwa:

"Each State Party Shall all times ensure that the investor and/or the convered investment will not be subjected to any denial of justice in criminal, civil, or administrative proceedings. ${ }^{15}$

Konten ini dimaksudkan untuk mencegah dan membatasi investor untuk menghindari penegakan hukum pidana di Indonesia, Jangan sampai, pemberantasan korupsi justru menjadi hal yang

15 Indonesian Global Justice. Workshop Paper: Comparison of Investment Chapter in RCEP, Op. Cit., 
menguntungkan bagi investor untuk mengugat pemerintah di arbitrase Internasional. Padahal sebagai negara yang berdaulat, investor Asing mesti tetap harus tunduk pada hukum nasional, sekalipun melakukan korupsi karena investor bukanlah negara, melainkan hanya individu-individu sebagaimana terkandung dalam Asas Par in Parem Non Hebet Imperium. ${ }^{16}$

\section{PENUTUP}

\section{a. Simpulan}

Gugatan investor ke Arbitrase Internasional melalui perjanjian investasi Internasional di Indonesia, justru dapat dimanfaatkan investor sebagai bargain position atas penegakan hukum korupsi yang dilakukannya sehingga berpotensi melemahkan pemberantasan korupsi itu sendiri. Konten FET merupakan celah hukum yang dijadikan dasar bagi investor atas gugatan tersebut. Ditambah lagi, penyelesaian sengketa dengan investor-State Dispute Settlement Mechanism di Arbitrase Internasional semakin menguatkan posisi investor untuk mengugat negara. Akibatnya, ini akan merugikan Indonesia dua kali lipat, bukan hanya kerugian akibat tindakan korupsi yang dilakukan pelakunya, juga biaya yang harus dikeluarkan pemerintah dalam sengketa arbitrase.

\section{b. Saran}

Berdasarkan pembahasan dalam kajian ini, maka rekomendasi penulis, yakni pertama Pemerintah perlu mencantumkan pelarangan tindak pidana korupsi dalam perjanjian investasi kita dengan investor baik dalam kegiatan pra, pasca maupun perpanjangan perjanjian investasi internasional di Indonesia seperti yang diberlakukan dalam India Model BIT. Kedua, sebaiknya Indonesia segera mengadopsi konsep FET dalam Indonesia-New Model BIT kita ke dalam perjanjian investasi baik yang bersifat Bilateral maupun multilateral. Pasalnya, konten FET dalam Indonesia New Model BIT membatasi gugatan di Arbitrase Internasional oleh investor jika pemerintah menegakan hukum pidananya, sekalipun dengan alasan denial of justice.

16 Patriana., Op.Cit. 


\section{REFERENS I}

Abdurrasyid, H. Priyatna. 2011. Arbitrase dan AlternatifPenyelesaian Sengketa (APS). Fikahati Aneska. Jakarta

Adolf, Huala. 2015. Dasar-Dasar, Prinsip, dan Filosofi Arbitrase Catatan Ke-2. Keni Media. Bandung.

Adolf, Huala. 2014. Hukum Perdagangan Internasional. PT. Raja Grafindo Persada. Jakarta.

Atmasasmita, Romli. 2010. Hukum Pidana Internasional dalam Rangka Perdamaian dan Keamanan International. Fikahati Aneska. Jakarta

BKPM. 2018. Realisasi Penanaman Modal PMDN dan PMA. http:// www2.bkpm.go.id/images/uploads/file_siaran_pers/Paparan_ Press_Release_TW_I_2018_-_IND.pdf. 28 Mei 2018.

Garner, Bryan A. 2004. Black's Law Dictionary (Eight Edition). Thomson West. USA.

Hamzah, Andi. 2008. Asas-Asas Hukum Pidana. Rineka Cipta. Jakarta

Hartanti, Evi. 2007. Tindak Pidana Korupsi. Sinar Grafika. Jakarta.

Cao, Tran Bao. 2017. Proving Corruption Allegation in International Arbitration. LLM Research Paper. Faculty Of Law.Victoria University of Wellington. https://researcharchive.vuw. ac.nz/xmlui/bitstream/handle/10063/6301/paper_access. pdf?sequence.24Mei 2018

Hapsari, Recca Ayu .2016. Pertanggungjawaban Negara terhadap Pengingkaran Keadilan dalam ArbitraseInternasional. Jurnal Ilmu Hukum Pranata Hukum,

Universitas Bandar Lampung. (11)1: 19-27.

Hwang, Michael and Kevin Lim. 2012. Corruption in Arbitration, Law andReality.AsianInternationalArbitrationJournal(AIAJ)(8)1:119. (http://www.arbitration-icca.org/media/4/97929640279647/ media013261720320840corruption_in_arbitration_paper_ draft_248.pdf. 26 mei 2018.

ICSID. Schedule Fee. https://icsid.worldbank.org/en/Pages/ icsiddocs/Schedule-of-Fees.aspx. 2 Juni 2018

Indonesian Global Justice. Workshop Paper: Comparison of Investment Chapter in RCEP, EU-Vietnam FTA. Workshop on 
Investment Portection and ISDS in Asia. 17-19 Nvember 2016. Manila, Philipina.

Johnson, Lise and Oleksandr Volkov. 2013. Investor-State Contracts, Host-State "Commitments" And The Myth of Stability In International Law. Center For International Commercial and Investment Arbitration, American University Washington College of Law. (24)3: 362-414. file:///C:/Users/ACER/Downloads/ SSRN-id2412592.pdf. 1 Juni 2018.

Kompas. 2012. Tiga Besar Sektor yang Rugikan Negara Akibat Korupsi. https://nasional.kompas.com/read/2012/o2/o5/23125634/ Tiga.Besar.Sektor.yang.Rugikan.Negara.akibat.Korupsi. $\quad 28$ Mei 2018.

Kontan. 2009. Newmont Harus Ganti Biaya Perkara US\$1,9 Juta. https://industri.kontan.co.id/news/newmont-harus-gantibiaya-perkara-us-19-juta. 1 Juni 2018.

Makhlouf, Hany H.2016. Corruption in the International Business Environment," The Journal of Human Resource and Adult Learning in University of the District of Columbia, USA (12)1: 32-39. http://www.hraljournal.com/Page/5\%2OHany\%20\%2O Makhlouf.pdf. 26 mei 2018.

Marsudi, H.E. Retno L. P. 2018. Annual Press Statement of The Minister For Foreign Affairs OfThe Republic Of Indonesia. https:// www.kemlu.go.id/id/pidato/menlu/Pages/PPTM2018\%2O MENLU\%2ORI\%2oENG.pdf . 28 Mei 2018.

Martin, A. TiMothy. 2002. International Arbitration And Corruption: An Evolving Standard. International Energy and Minerals Arbitration, Mineral Law Series. http://timmartin.ca/ wp-content/uploads/2016/o2/Int-Arbitration-CorruptionMartin2002.pdf. 27 Mei 2018.

Mauna, Boer. 2015. Hukum International Pengertian Peranan dan Fungsi dalam Era Dinamika Global Alumni. Bandung.

NGO-Transnational Institute. 2016. Back to Basic: The Most Common Pro-ISDS claims are not supported by Evidence. Winning The Debate, Against Pro ISDS Voice, An Activist's Argument Guide. https://www.ttip-stoppen.at/wp-content/uploads/2016/o8/ winning-the-debate-against-pro-isds-voices.pdf. 1 Juni 2018.

Nugroho, Susanti Adi. 2015. Penyelesaian Sengket Arbitrase dan Penerapan Hukumnya. Kencana. Jakarta 
Parthiana, I Wayan . 1990. Pengantar Hukum Internasional. Mandar Maju. Bandung

Pusat Kebijakan Regional dan Bilateral Kementerian Keuangan RI, “Kajian Kerja sama Bilateral Indonesia - Amerika Serikat,” 2012.

Reeder, Matt. 2016. State Corruption in ICSID BITArbitration: Can it be Estopped? Center For International Commercial and Investment Arbitration, American University Washington College of Law (27)3: 311-325. http://arbitrationblog.kluwerarbitration. com/2017/o3/o9/state-corruption-in-icsid-bit-arbitration.27 Mei 2018.

Sachet and Sooraj. 2013. Investor-State Dispute Settlement Mechanism: The Quest for a Workable Roadmap. Utrech Jurnal of International and European Law. (29) 76:89-90. file://C:/ Users/ACER/Downloads/41-41-1-PB.pdf. 1 Juni 2018.

Transparancy International. 2017. Corruption Perception Index 2017. https://www.transparency.org/news/feature/corruption_ perceptions_index_2017. 2 Juni 2018.

UNCTAD. Indonesian Bilateral Investment Treaties. http:// investmentpolicyhub.unctad.org/IIA/CountryBits/7. 28 Mei 2018.

UNCTAD. 2012. Fair and Equitable Treatment. http://unctad.org/ en/Docs/unctaddiaeia2011d5_en.pdf. 1 Juni 2018

UNCTAD. 2017. ISDS: Review of Development in 2017 http://unctad. org/en/PublicationsLibrary/diaepcbinf2018d2_en.pdf. 1 Juni 2018.

Vandevelde, Kenneth J. 2010. A Unified Theory of Fair and

Equitable Treatment. NewYork University Journal of International Law \& Politics (43)1:44-104 file://C:/Users/ACER/Downloads/ SSRN-id2357642\%2O(1).pdf. 1 Juni 2010.

Vas, Hilde Van Der dan Riza Damanik. 2014. The Case of NewmontMining. https://www.tni.org/files/download/ newmont-indonesia-case-4.pdf. 1 Juni 2018.

Wellhausen, Rachel. 2016. Recent Trends in Investor-State Dispute Settlement. Journal of International Dispute Settlement (Forthcoming) in University of Texas at Austin (7)1: 117135. http://www.rwellhausen.com/uploads/6/9/o/o/69oo193/ wellhausen___recent_trends_in_isds.pdf. 2 Juni 2018. 
Widyana, I Made. 2011. Alternatif Penyelesaian Sengketa dan Arbitrase. Fikahati Aneska. Jakarta.

WorldBank. 1988. Amco V. Republic of Indonesia: Resubmitted Decision On Juridiction. ICSID Review- Foreign Investment Law Journal (3)1. http://icsidfiles.worldbank.org/icsid/ ICSIDBLOBS/OnlineAwards/C126/DC66 3_En_old.pdf. 1 juni 2018.

Zayas, Alfred Maurice De. Report of the Indenpent Expert on The Promotion of a Democratic and Equitable International Order," Human Right Council in Thirtieth Session. UN General Assembly $\mathrm{A} / \mathrm{HRC} / 3 \mathrm{O} / 44$.

\section{Perundang-Undangan}

Republik Indonesia, Undang-Undang tentang Arbitrase dan Alternatif Penyelesaian Sengketa, Nomor 30 Tahun 1999 Republik Indonesia. Undang-Undang Perjanjian Internasional. Nomor 24 Tahun 2000.

\section{Arbitration Award}

Al-warraq Award, ICSID Case No. ARB/11/13. https://www.italaw. com/sites/default/files/case-documents/italaw4164.pdf. 26 Mei 2018.

Curchill Mining V. Indonesia Award https://www.italaw.com/sites/ default/files/case-documents/italaw7893.pdf. 1 Juni 2018.

India Model BIT. https://www.mygov.in/sites/default/files/ master_image/Model\%2OText\%2ofor\%2othe\%2oIndian\%2O Bilateral\%2oInvestment\%2oTreaty.pdf. 28 Mei 2018

Metal Tech Award, ICSID Case No. ARB/10/3. https://www.italaw. com/sites/default/files/case-documents/italaw3012.pdf.27 Mei 2018

Niko Resource Award, ICSID Case No. ARB/10/18, https://www. italaw.com/sites/default/files/case-documents/italaw6322_o. pdf. 25 Mei 2018.

Word Duty Free Award, ICSID Case No. ARB/oo/7. https://www. italaw.com/documents/WDFv.KenyaAward.pdf. 27 Mei 2018. 